Preprints of the

Max Planck Institute for

Research on Collective Goods

Bonn 2010/08

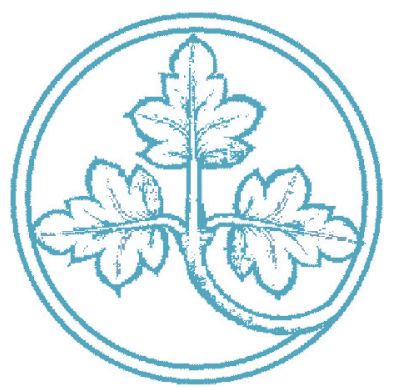

The Political Economy of Agricultural Protection: Sweden 1887

Sibylle H. Lehmann /

Oliver Volckart

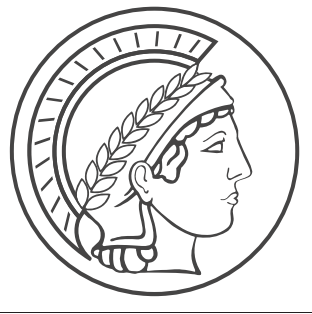




\section{The Political Economy of Agricultural Protection: Sweden 1887}

Sibylle H. Lehmann / Oliver Volckart

March 2010 


\title{
The Political Economy of Agricultural Protection: Sweden 1887
}

\section{Sibylle H. Lehmann ${ }^{*}$ / Oliver Volckart ${ }^{\ddagger}$}

\begin{abstract}
We analyse the Swedish general elections that took place in spring and autumn 1887. Our aim is to discover which groups of voters were responsible for the severe losses that the supporters of free trade suffered in the second of these contests, and that allowed the protectionists to gain the majority in parliament and to initiate a new tariff policy. We find that while capital owners and wage earners consistently favoured free trade, in the spring election only the largest farmers supported protectionism. By autumn, political preferences among smallholders and middling farmers had shifted in favour of protectionism, too. As these groups were not specialised in the production of import competing goods, we assume that the political landslide in the autumn elections can be attributed to the influence of anti-free trade propaganda.
\end{abstract}

JEL Classification: N43, N53, N73

Keywords: voting, election analysis, tariffs, trade policies

\section{Contents}

1. The elections of 1887 and Sweden's turn to protectionism .......................................... 2

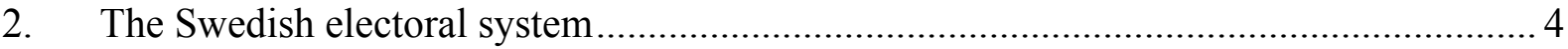

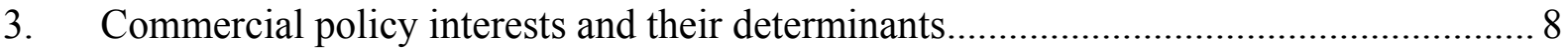

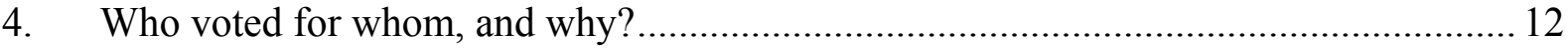

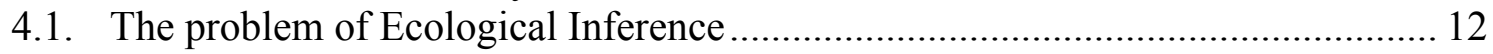

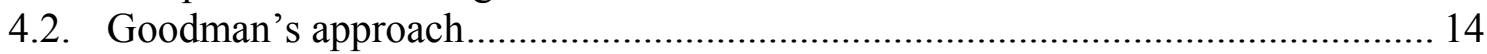

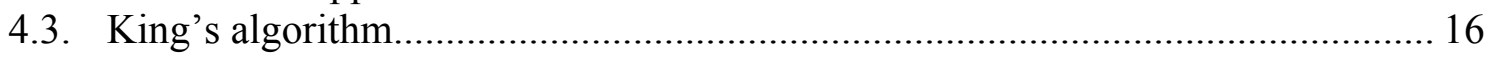

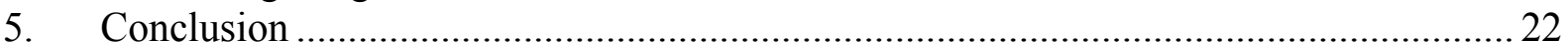

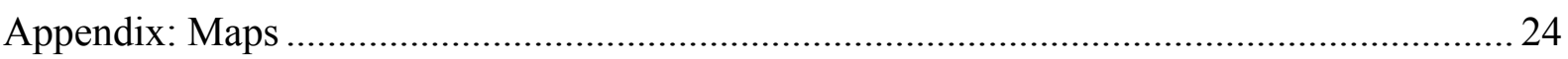

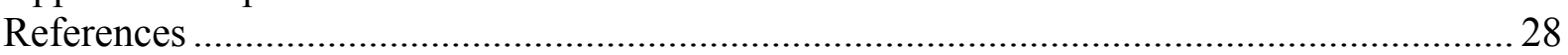

Max Planck Institute for Research on Collective Goods, Kurt-Schumacherstr. 10, 53113 Bonn, Tel: ++49 (0)2289141636, lehmann@coll.mpg.de

* London School of Economics and Political Science, Economic History Department, Houghton Street, London WC2A 2AE, Tel: +44 (0)20 7955 7861, o.j.volckart@lse.ac.uk 


\section{The elections of $\mathbf{1 8 8 7}$ and Sweden's turn to protectionism}

From the 1870s, Sweden like other European countries experienced what has been called a 'grain invasion' from America and Russia (O'Rourke, 1997). The average yearly import of rye trebled from the 1860 s to the 1880 s, while that of wheat grew sixteen fold. Between 1861 and 1870, only 11 percent of the rye and 5 percent of the wheat consumed in Sweden had been imported; by the 1880s, these shares had grown to 27 and 46 percent, respectively (Lindahl et al., 1937: $30 \mathrm{ff}$.). Falling international transport costs caused similar developments where commodities produced by the raw material and capital goods industries were concerned (National Central Bureau of Statistics, 1972: 198 ff.).

Whereas a number of countries, notably Great Britain and Denmark, retained their free trade orientation in the face of such pressures, Sweden joined France and Germany in imposing tariffs on agricultural and industrial imports. Kevin O'Rourke (1997: 778 ff.) argued that where agriculture was concerned, the political choices of governments were related on the one hand to how the grain invasion affected land rents, and on the other to the weight of agricultural interests in domestic politics. A similar argument can be made for industrial imports. As for Sweden, land rents and industrial profits were negatively affected by the shifts in the sectoral trade balances since the 1870 s, and in reaction, interest groups demanding tariffs were formed (Esaiasson, 1990: 83 ff.). The issue dominated two elections held in spring and autumn 1887. Both returned free trade majorities. The relevant literature accordingly argues that Sweden's turn to protectionism a year later was not due to these elections, but rather to a political scandal (Verney, 1957: 107; Lewin, 1988: 46 f.): After the autumn election, the protectionists discovered that one of the members for Stockholm - who all supported free trade had neglected to pay a negligible amount of his taxes. Electoral law did not only disqualify this member but, owing to an oversight in its framing, the other twenty-two members for Stockholm, too. The votes cast for them were declared invalid, which gave the protectionists the majority. Still, this does not mean that the elections did not play a crucial role in the switch to a new tariff policy. If the Stockholm free traders had been forced to resign in favour of the protectionists some time after the spring election, the majority in parliament would have been be weaker but unchanged in favour of free trade. Free trade supporters would still have had a majority of 7 seats over the protectionists (see Table 1). It was the autumn election that fatally weakened the free trade cause. Only now were the protectionists able to gain a majority by ousting 23 free trade supporters, and only now were they able to form a new government that brought about the change in trade policies.

Apart from their political importance, there is another reason why it is rewarding to study the two Swedish elections where commercial protection was at the core of the dispute: In Sweden as elsewhere, we can expect tariffs on imports to have affected different social and economic groups in different ways. At the most basic level, industrial tariffs benefitted capital owners and agricultural tariffs farmers, whereas all other groups suffered from the rising prices, but this is only the broadest picture. Agriculture was nowhere homogeneous; farm size and the degree and type of specialisation complicate the issue. Thus, large landowners who regularly 
supplied grain to the market would gain from protection whereas smallholders may have produced for home consumption only. Tariffs would then not affect them. Likewise, farmers specialising in the production of wheat or rye naturally benefitted from protection, but others, who specialised in animal husbandry may have needed to buy grain as fodder; consequently tariffs would harm them.

In Sweden, bread grain producers - especially wheat farmers - were hit hardest by the commercial changes that took place from the 1870 s to the 1880 s. Owing to the specific nature of most capital goods needed for grain farming, they were unable at short notice to transfer their assets to less import competing sectors. Trade models such as the specific factors model used to analyse the commercial policy preferences of voters would predict them to favour protectionism (cf. Viner, 1931). Farmers focusing on animal husbandry, by contrast, were not exposed to increasing competition from abroad: Pork imports may have grown, but the prices remained relatively stable in the long run, given that they were quite variable in the short run (National Central Bureau of Statistics, 1972: 196; Jörberg, 1972: 320 f.). Other animal products, such as milk or cheese were no important import commodities at all. Pig and dairy farmers can therefore be expected to have been indifferent or to have favoured free trade. ${ }^{1}$ As the introduction of tariffs on goods produced for the home market by the raw material and capital goods industries was also discussed in 1887 (Bohlin, 2005: $14 \mathrm{f}$.), voters with capital incomes should have supported protectionism, too.

While not neglecting capital owners and voters who earned wages, we will focus on the agricultural sector for two reasons. First, the majority of the population and voters were working in agriculture. In 1887 they constituted roughly 65 percent of the entire working population (Lindahl et al., 1937: 2). Second, because land is an immobile factor of production, we can define the tariff political interests of farmers in regional terms. However, when we try to determine the interests of capital owners, mobility is a problem: We can not be sure if they cast their votes at the place where they invested their assets. In consequence, constituencies with capital intensive industries did not necessarily have voters who received the main part of their income from capital returns. This leaves us with a number of different types of farmers, i.e. of farmers who worked estates of different sizes and were specialised in different ways. Asking if their commercial policy interests matched the expectations that can be derived from trade models - that is, if their behaviour can be considered rational - is well worth the effort.

As for prior research, studies that aim at answering questions concerning the link between commercial policy interests and voting behaviour have repeatedly been undertaken in the context of late nineteenth-century history (e.g. Klug, 2001). However, most of them used traditional econometric approaches such as simple logistic regressions that, when applied to voting, can produce problematic results. Modern election analysis offers tools - in particular King's algorithm - which provide far superior estimates. By providing point estimates and

The issue of the homogeneity of agriculture has been extensively debated. Much of the relevant literature (Gerschenkron, 1943; Webb, 1982; Schonhardt-Bailey, 1998; Klug, 2001; Lehmann, 2010) refers to Imperial Germany. However, Bohlin (2009) recently extended the debate to Sweden. 
confidence intervals for the votes of different groups of voters for every constituency, it extracts much more information from the available data than simpler methods. King's Algorithm is introduced in detail below; for the present, suffice to say that the method here applied is superior to older approaches.

To date, there are only two historical cases where King's algorithm has been applied: Gary King et al. (2008) examined Weimar Germany in order to show who voted for Hitler, and Sibylle Lehmann (2010) analysed elections in Imperial Germany to determine which groups of voters were responsible for the country's turn to protectionism. Swedish nineteenth-century elections have never been studied from this perspective, and have in general received little attention. Elis Håstad (1941) provided a basis for further analyses by determining the political affiliations of the candidates in the two elections of 1887 and in the one of 1890. Leif Lewin et al. (1976) estimated the impact of the social structure on voting behaviour in the period from 1887 to 1968 . This is the only quantitative attempt to investigate the electorate and its voting behaviour in Sweden. Lewin et al.'s work provides a good overview of the electorate but is not detailed enough to compare the voting behaviour of different categories of farmers and of other occupations with expectations derived from trade models or empirical results. The authors grouped occupations with similar voting behaviour and analysed this for just four extracted groups. Some political scientists, for instance Peter Esaiason (1990), have studied electoral campaigns during this period, but in a rather descriptive way. With regard to trade policy, Jan Bohlin $(2005 ; 2009)$ focused on the actual effective tariffs protection in the late nineteenth and early twentieth centuries, and the impact of tariffs on the income of different groups of farmers. How the decision to introduce tariffs came about, and how the electorate voted in this context, are issues outside the scope of his research. These are questions that the available data and modern methodology allow us to analyse in much more detail than prior research has been able to do.

The rest of the paper is organised as follows. We first provide an overview of Swedish electoral law (section 2). Thereafter, we discuss the formation of commercial policy interests (section 3). Following this, we present our analysis and its results (section 4), and a final section concludes.

\section{The Swedish electoral system}

At the time of the tariffs debates, Sweden had a two-chamber system where a law had to be accepted in both chambers with simple majority (Verney, 1957: $50 \mathrm{ff}$.; Särlvik, 2002: 232 f.). The First Chamber was elected by the councils of the provinces (läns) and by cities outside the provinces; it does not concern us here. The Second Chamber was more popular in character; it was elected in general elections by all enfranchised citizens. However, in late nineteenth-century Sweden the franchise was still severely restricted. The electoral law passed in 1866 and valid until the reform bill of 1907 stipulated that voters had either to own real estate of a taxable value of at least 1,000 kronor, or for at least five years had leased farm property 
whose taxable value exceeded 6,000 kronor, or paid taxes on an income of at least 800 kronor p.c. a year. ${ }^{2}$ In 1885 , there were about 330,000 enfranchised persons in Sweden, almost 240,000 of who had gained the right to vote because they owned estates. Only about 11,000 were leaseholders, and fewer than 80,000 owed their voting right to their income. In the different constituencies, the rate of enfranchisement varied between c. 3 and just over 10 percent of the population (BISOS, 1885: $74 \mathrm{f}$;; 1887: XIV ff., 230).

The constituencies were formed on the basis of the administrative units below the provinces (called härad, domsaga or fögderi), with most consisting of between one and five such districts. When they were constituted, the aim was to form one for c. 40,000 inhabitants each. Towns composed their own constituencies. Those with a population of 10,000 or more formed one each where one member was elected for every 10,000 residents, while smaller towns could group together and form separate constituencies, electing one member for every 6000 inhabitants (Verney, 1957: $52 \mathrm{f}$ ). This measure seems to have been designed in order to make up for the smaller share of persons entitled to vote in small towns. In 1885, on average 1700 eligible voters were registered per constituency (BISOS, 1885: $46 \mathrm{ff}$.). Altogether, there were 186 constituencies, 41 of which were urban. The law of 1866 created a mixed system of direct and indirect elections. Voting was to be direct in towns that returned members of their own and indirect where a large constituency was formed by a group of districts or small towns. However, districts and small towns could choose to elect members directly, which they increasingly did (Verney, 1957: 53). By spring 1887, only 60 indirect constituencies were left; by autumn, that number had fallen to 41 (Caramani, 2000). In some of these voting seems to have been open - making instances of group and other pressures more likely -, but elsewhere it was always by secret ballot (Särlvik, 2002: 232).

The electoral law also stipulated that elections had to be held every three years regardless of additional elections that might have to take place in between due to the dissolution of the parliament by the king. Actually, this is what happened in 1887 (Verney, 1957: 106 f.). In the years before, the protectionists had gradually gained ground in the First Chamber, and a first law in favour of tariffs had been passed in the Second Chamber. Before a joint vote could be taken, King Oskar II - pleased to be able to demonstrate his political power and to use his dissolution prerogative - dissolved parliament. The government that had suggested this measure aimed at achieving a clearer picture about public opinion (Anderson, 1955/70: $373 \mathrm{f}$.). In consequence, an extraordinary election in March 1887 became necessary, but the regular election of autumn 1887 was held regardless.

Both elections of that year were overshadowed by the tariff issue to such a degree that they more closely resembled referenda about tariffs. Campaigning in spring of 1887 was intense, with statements about the tariff question dominating. Many candidates published so-called 'political confessions' in local newspapers, in which they stated whether they were free trade

The law of 1866 actually determined the values in riksdaler. For the relation between riksdaler and kronor (used from 1873) see Jörberg (1972: 79 ff.). 
or tariff supporters (Esaiasson, 1990). Another new trend was the appearance of interest groups all over the country, for instance the 'Friends of Swedish Work' who demanded specific tariffs, and the 'Union against Food Tariffs', whose members favoured free trade. Most of these organisations were founded by parliamentarians (Esaiasson, 1990: $83 \mathrm{ff}$.). Initially, there was a huge upsurge in interest. Overall turnout increased from c. 26 percent of the eligible voters in 1884 to more than 66 percent in spring 1887, with participation in rural areas, where involvement in political discussions was usually weak, growing particularly strongly. By autumn, however, a certain voter fatigue could be observed. Average turnout fell to c. 37 percent, rural turnout to 32 percent (Caramani, 2000).

The way the results of these elections were reported to the public differed from that of later contests. Political parties were only beginning to develop in late nineteenth-century Sweden (Verney, 1957: 98 ff.). In consequence, national statistics do not give the results by party, but rather the names of the candidates and the numbers of votes they received (BISOS, 1888: 45 ff.). In order to determine how the electorate voted in spring and autumn 1887, it is therefore necessary to establish the political leaning of each individual member elected to parliament. This has been done on the basis of public statements, brochures and newspaper reports, which contain sufficient information to allow the identification of each candidate as either free trade supporting or protectionist (Håstad, 1941). Table 1 provides an overview of the results.

Table 1: Results of the Swedish general elections 1887

\begin{tabular}{|c|c|c|c|c|c|c|}
\hline & \multicolumn{2}{|c|}{$1887 a$} & \multicolumn{2}{|c|}{$1887 b$} & \multicolumn{2}{|c|}{$\begin{array}{l}\text { 1887b post- } \\
\text { replacement* }\end{array}$} \\
\hline & Seats & in Percent & Seats & in Percent & Seats & in Percent \\
\hline Free-Trader & 136 & 61.54 & 125 & 56.31 & 103 & 46.4 \\
\hline Protectionist & 85 & 27.78 & 97 & 43.69 & 119 & 53.6 \\
\hline Total & 221 & 100 & 222 & 100 & 222 & 100 \\
\hline
\end{tabular}

Source: Håstad (1941).

* Results after the replacement in the Stockholm parliaments.

As a result of the tax scandal described in the introduction, a protectionist majority was established. ${ }^{3}$ This majority formed a new government, and in 1888 tariffs were introduced for a number of agricultural and industrial products (Bohlin, 2005).

Despite the consistent free trade majority that the elections of 1887 showed, there were interesting shifts between spring and autumn, and interesting regional differences. Figure 1 shows the geographic distribution of the electorate's preferences:

Håstad (1941: 123 f.) suggested that the pro-tariff majority created by the disqualification of the Stockholm free-trader election slate actually meant that parliament reflected public opinion better. He argues that, although the population preferred protectionism, they did not gain the majority in the parliament because: a) the restricted suffrage allowed just a small number of people to vote in rural areas, where people tended to support protectionists; and b) the turnout was higher in cities, which were generally more freetrade-orientated than rural areas. Thus, he claims that constitutional restrictions combined with a lower motivation among protectionists to vote biased the electoral result to the benefit of free-traders. 


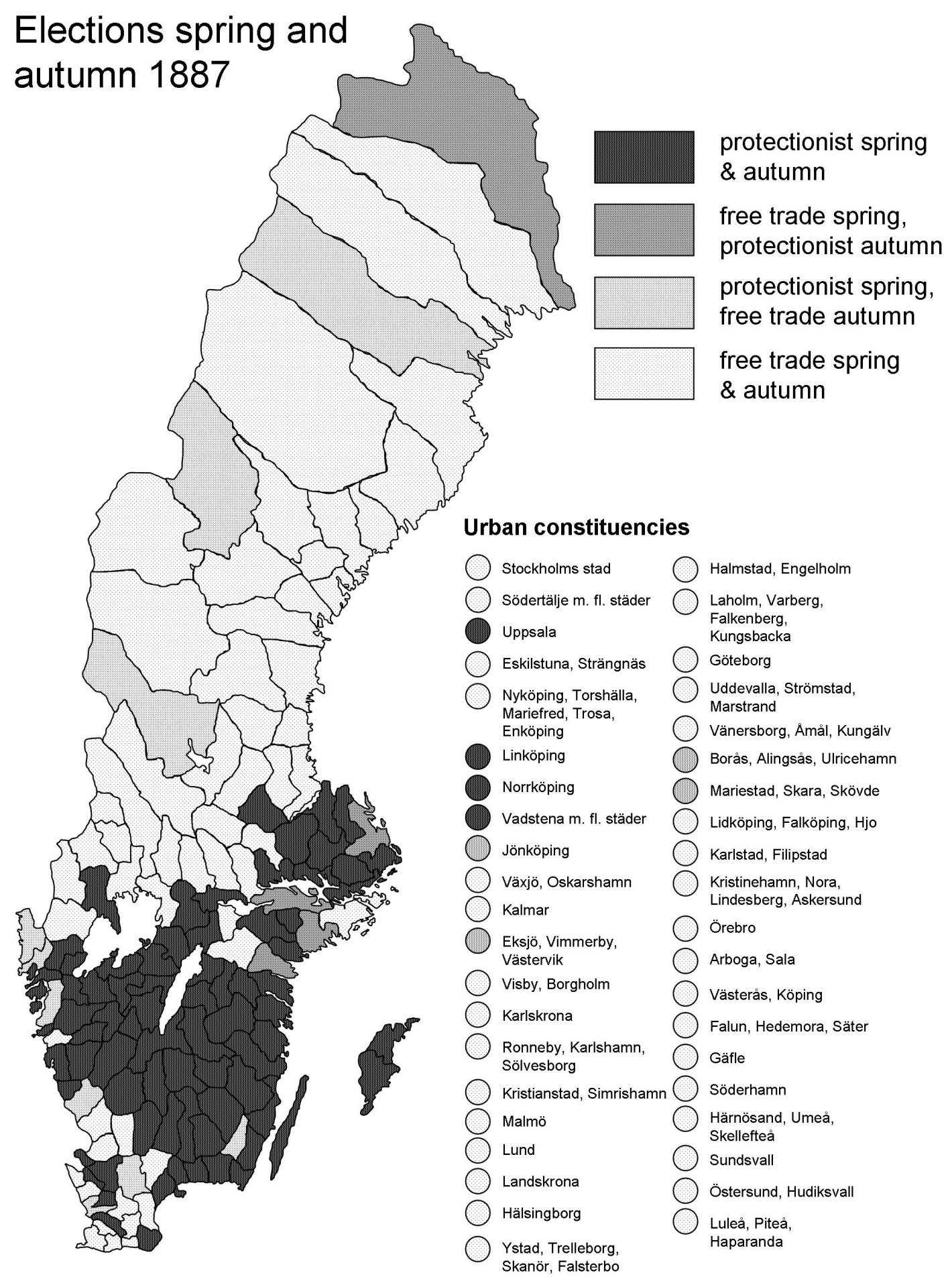

Source: Håstad (1941: 128 ff.).

Practically the whole country north of Uppsalas län was firmly pro free trade, and free traders had further strongholds in Malmöhus and Halland. The protectionists, by contrast, were strong in the rest of the south and on the islands of Öland and Gotland. 


\section{Commercial policy interests and their determinants}

In determining how these trade political interests related to income and occupational specialisation, we discuss wage earners and capital owners only in passing. We do have information on their income (BISOS, 1885: $46 \mathrm{ff}$.), but we can not be certain if or to what degree this derived from capital returns. It might also just reflect high wages. Moreover, as mentioned in the introduction, even if they received a capital income only, we can not assume that they invested their assets at the place where they cast their vote.

Focusing on the remaining groups of voters, i.e. on those who owned or leased land, we need to determine if their specialisation on grain farming or animal husbandry matched their preferences for protectionism or free trade, respectively. Unfortunately, Swedish national statistics do not provide data on the agricultural specialisation of the voters. What they do provide is detailed information on the value of the estates that the voters held (BISOS, 1885: $46 \mathrm{ff}$.). Relating this information to Swedish land values from 1887 (Lindahl et al., 1937: 393) allows us to estimate the size of the farms owned or leased by the voters. In addition, we can use constituency-level data on the area of farmland on the one hand, and on the output of wheat and rye and on the numbers of dairy cows and pigs on the other (BISOS, 1890).

Bohlin (2009: 12), who examined the long-term income distributional effects of the tariffs introduced since the late $1880 \mathrm{~s}$, found a close match between farm size and specialisation: the larger the farm, the higher the degree of specialisation on bread grain production. He used detailed post-World War I data on the output mix of farms of different sizes (Höijer, 1921). Still, we can not simply assume that his results hold for our period, too. One of Bohlin's (2009: $7 \mathrm{f}$.) core hypotheses is that owing to the high income elasticity of demand for meat and dairy products and the strong export demand in particular for butter, Swedish agriculture experienced an ongoing transformation in the direction of more animal produce in the late nineteenth and early twentieth centuries. In 1887, livestock farming was clearly less important than thirty years later. However, how important was it? Where was it concentrated, and can we relate its geographical concentration to free trade strongholds?

Figure 2 below shows the geographical distribution of farm sizes, while figures 3 to 6 (appendix) provide a general overview of that of bread grain production and animal husbandry. The maps are based on data collected in 1888 (BISOS, 1890), i.e. early enough for the introduction of tariffs not to have affected the sectoral structure. 


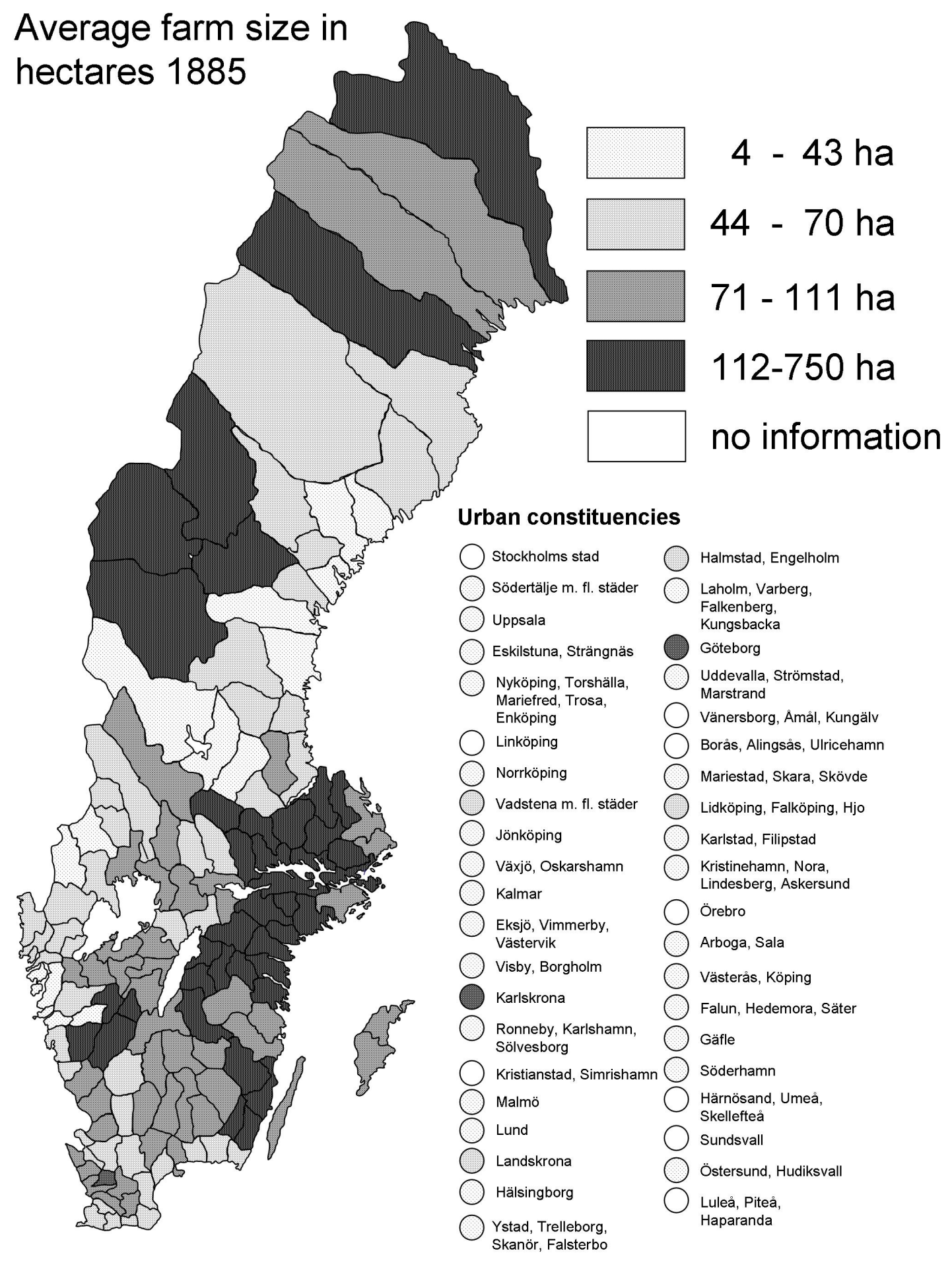

Source: BISOS (1890).

Farm sizes differed clearly between regions. Large estates existed in the neighbourhood of cities such as Stockholm, Kalmar and Göteborg and in densely urbanised Södermans län and Östergotland; in the north-west and extreme north of Sweden farms were also large. By con- 
trast, smaller farms and smallholdings prevailed in less densely urbanised and more marginal parts of the country, i.e. in parts of the south and in Central Sweden. As for bread grain production, we are considering the quantities of wheat and rye produced per hectare of agriculturally used land, which we here define as land used as garden, arable and pasture (BISOS, 1890). Thus, we exclude both managed and unmanaged woodland. Wheat farming was concentrated around Stockholm, in Södermans län and in Malmöhus. In the north, owing to climatic conditions, it practically did not occur, but it was also of minor importance in many southern regions, e.g. in Kronobergs län. Rye farming, too, was very rare in the north, being concentrated in middle Sweden and in the coastal districts of the south-east. Estimating the numbers of cows and pigs per hectare of farmland shows that dairy and pork farming were more unevenly distributed. Dairy farming was strong in middle Sweden, on parts of the west coast and in the extreme south east of the country. Pig farming, by contrast, was strong in Malmöhus and Kristanstads län and in parts of Vesternorrlands län. In the 1880s it still was to some extent an urban phenomenon. In many of the urban constituencies the residents were producing pork, with the density of pigs being as high as in some rural districts.

While a geographical representation shows a vague association of farm size and specialisation - where farms were large, farmers seem to have produced more wheat; where holdings were small, they appear to have had more cows or pigs per unit of land - table 2 shows the link more clearly. We picked the constituencies where the output of bread grain and the number of dairy cows per hectare farmland was highest, and analysed the distribution of farm values and types of properties owned or leased by the voters. Obviously, due to the restricted suffrage smaller landholdings are underrepresented here, because owners of theses estates were excluded from voting. 
Table 2: Overview structure of voters owning farms in the wheat and dairy dominated constituencies

\begin{tabular}{|c|c|c|c|c|c|}
\hline Wheat dominated constituencies & obs & $\begin{array}{r}\text { On ave- } \\
\text { rage }\end{array}$ & std dev. & $\min$ & $\max$ \\
\hline $\begin{array}{l}\text { Voters owning agricultural land worth } \\
1000-2000 \text { Kronor }\end{array}$ & 54 & 0.082 & 0.072 & 0.000 & 0.279 \\
\hline $\begin{array}{l}\text { Voters owning agricultural land worth } \\
2000-10,000 \text { Kronor } \\
\text { Voters owning aqricultural land worth }\end{array}$ & 54 & 0.268 & 0.197 & 0.000 & 0.700 \\
\hline $\begin{array}{l}10,000-30,000 \text { Kronor } \\
\text { Voters owning agricultural land worth }\end{array}$ & 54 & 0.135 & 0.097 & 0.000 & 0.299 \\
\hline more than 30,000 Kronor & 54 & 0.017 & 0.015 & 0.000 & 0.052 \\
\hline Voters owning other estates & 54 & 0.200 & 0.192 & 0.014 & 0.652 \\
\hline Leaseholders & 54 & 0.081 & 0.082 & 0.000 & 0.289 \\
\hline onstituencies & obs & $\begin{array}{r}\text { On ave- } \\
\text { rage }\end{array}$ & std dev. & $\min$ & $\max$ \\
\hline $\begin{array}{l}\text { Voters owning agricultural land worth } \\
1000-2000 \text { Kronor } \\
\text { Voters owning aqricultural land worth }\end{array}$ & 52 & 0.103 & 0.100 & 0.000 & 0.569 \\
\hline $\begin{array}{l}2000-10,000 \text { Kronor } \\
\text { Voters owning agricultural land worth }\end{array}$ & 52 & 0.327 & 0.260 & 0.000 & 0.814 \\
\hline $\begin{array}{l}10,000-30,000 \text { Kronor } \\
\text { Voters owning agricultural land worth }\end{array}$ & 52 & 0.078 & 0.074 & 0.000 & 0.253 \\
\hline more & 52 & 0.006 & 0.008 & 0.000 & 0.038 \\
\hline Voters owning other estates & 52 & 0.233 & 0.219 & 0.004 & 0.653 \\
\hline Leaseholders & 52 & 0.018 & 0.039 & 0.000 & 0.222 \\
\hline
\end{tabular}

Source: BISOS (1890).

As for bread grain farming, we consider wheat because in the course of the grain invasion the growth in imports affected producers of wheat more severely than producers of rye (c.f. p. 2). We examine 54 constituencies, i.e. the 30 percent with the highest wheat output per hectare agricultural land. Owing to the availability of data, in the case of dairy farming the 30 percent consist of the 52 constituencies where the number of cows per hectare farmland was highest. Both in the case of wheat production and in that of dairy farming, a high proportion of the voters held farms of medium size, having a value between 2000 and 10,000 kronor (27 and 33 percent, respectively). However, where wheat farming dominated, voters from small farms were rarer ( 8 percent) than where farms focused on dairy production (10 percent). By contrast, voters with large farms, whose value exceeded 10,000 kronor, were more common in constituencies where wheat was produced than in those where farmers held cattle (14 vs. 8 percent). Leaseholders and owners of land that the Swedish national statistics classified as non-agricultural have been included for the sake of completeness. Altogether, we can conclude that the tendency of large estates to specialise on bread grain production while smallholdings focused on animal husbandry, which Bohlin (2009) established on the basis of postWorld War I data, was evident already at the end of the 1880s. Given these results, we would expect voters who owned large farms to favour protection and smallholders to vote for free trade - in other words, we are able to use farm sizes as an indicator of the specialisation and political views of the voters. 


\section{Who voted for whom, and why?}

\subsection{The problem of Ecological Inference}

Our analysis proceeds in three steps: First, we discuss a problem that commonly besets election analyses such as ours - that of Ecological Inference, then, we analyse the data with the help of a traditional approach to voting analysis, i.e. Goodman's regression, and finally, we check and refine our preliminary results using King's algorithm.

In the introduction, we already briefly mentioned the Ecological Inference problem and promised a detailed discussion. This is indeed necessary as Ecological Inference commonly biases analyses such as ours. The nature of this problem can in fact very well be explained on the basis of our preliminary analysis. Thus, we know how many votes were cast for free-tradesupporting candidates and how many for protectionists in the Swedish elections of 1887, and we can estimate how many voters were dairy and how many wheat farmers. This information is available for every constituency. What we are interested in is the voting behaviour of individuals, or at least of sub-aggregates, for example how many farmers with farms between 2.3 and 4.6 hectares - i.e. those from the lowest property bracket - voted for free trade in a particular constituency. Why is answering such a question a problem? Assume that in one constituency, 30 percent of the electorate consisted of those dairy farmers and that 30 percent of the votes were cast for candidates who supported free trade. In another constituency, 40 percent of the electorate consisted of such farmers and 40 percent of votes were cast for freetrade-supporting candidates. It thus seems that there is a perfect positive correlation of farmers with farms between 2.3 and 4.6 hectares and votes for free trade. However, regardless of how intuitive this relationship may be, farmers with farms between 2.3 and 4.6 hectares may actually not have voted for free trade at all. The votes for free trade may have come from industrial workers, who could conceivably favour free-trade-supporting candidates in constituencies dominated by agriculture. Hypothesising about the behaviour of individuals by using aggregate data can therefore be misleading: It means making inferences without considering the social environment of the individuals concerned. This is why the problem is called that of Ecological Inference. It is well known in political science: William Ogburn and Inez Goltra (1919) introduced it in the very first multivariate statistical analysis ever to have been published in a political science journal, and it has been among the longest-standing unsolved problems in quantitative social science (King, 1997). Because of it, we can not be sure that the impression of a close association between farm size and preference for free trade or protection, which we gained above, is actually correct.

Table 3 shows how the problem can be illustrated in a formal manner. Suppose we want to find out whether or not workers in a specific sector voted for parties that supported free trade. The table shows the problem for one constituency and for two groups of voters, i.e. for those favouring free trade and protection, respectively. Here the workers employed in sector $\mathrm{J}$ are the voters of interest. 
Table 3: The Ecological Inference problem for constituency i and occupation J

\begin{tabular}{|c|c|c|c|c|c|}
\hline & \multicolumn{3}{|c|}{ Voting decision } & \multirow[b]{2}{*}{$\begin{array}{l}\text { Abstentation } \\
\text { in percent }\end{array}$} & \\
\hline & $\begin{array}{l}\text { Share of } \\
\text { votes for free } \\
\text { trade }\end{array}$ & $\begin{array}{l}\text { Share of } \\
\text { votes for } \\
\text { protection }\end{array}$ & $\begin{array}{l}\text { Turnout in } \\
\text { percent }\end{array}$ & & \\
\hline $\begin{array}{l}\text { Share of work- } \\
\text { ers in sector } \mathrm{J}\end{array}$ & $\lambda_{i}^{J}$ & $1-\lambda_{i}^{J}$ & $\beta_{i}^{J}$ & $1-\beta_{i}^{J}$ & $X_{i}^{J}$ \\
\hline \multirow[t]{2}{*}{$\begin{array}{l}\text { 1-Share of } \\
\text { workers in sec- } \\
\text { tor } \mathrm{J}\end{array}$} & $\lambda_{i}^{-J}$ & $1-\lambda_{i}^{-J}$ & $\beta_{i}^{-J}$ & $1-\beta_{i}^{-J}$ & $1-X_{i}^{J}$ \\
\hline & $V_{i}$ & $1-V_{i}$ & $T_{i}$ & $1-T_{i}$ & $N_{i}$ \\
\hline
\end{tabular}

Note: $x_{i}^{J}$ is the share of the workforce in constituency i employed in sector $J$. This could be, for example, the share of farmers. $V_{i}$ is the share of votes for free-trade-supporting parties in the constituency $\mathrm{i}$ and $1-V_{i}$ the share of votes for parties that support protection. $T_{i}$ is the percentage turnout. These values are known. The unknown quantities of interest are: $\lambda_{i}^{J}$, which is the share of workers in sector $\mathrm{J}$ in the constituency $\mathrm{i}$ that voted for free $; \lambda_{i}^{-J}$, which is the share of workers of sectors outside $\mathrm{J}$ that voted for free trade; $\beta_{i}^{J}$, which is the turnout of the workers in sector $\mathrm{J}$ in the constituency $\mathrm{i}$; and $\beta_{i}^{-J}$, which is the turnout of workers in other sectors.

For every constituency, national statistics provide the values in the margins of the table, where index i indicates constituency $\mathrm{i}$, and $\mathrm{J}$ indicates sector $\mathrm{J} . X_{i}^{J}$ is the share of the workforce in constituency i employed in sector J. This could be, for example, the share of farmers with between 2.3 and 4.6 hectares constituency i. $V_{i}$ is the share of votes for free-tradesupporting parties in constituency $i$ and $1-V_{i}$ the share of votes for parties that support protection. $T_{i}$ is the percentage turnout for constituency $\mathrm{i}$. What these statistics do not show, however, are the values in the inner (framed) cells of the table, such as the shares of various occupations in a particular constituency that voted for free trade, for protection, or abstained; that is the $\lambda_{i}$ 's and $\beta_{i}$ 's, which are not directly observed. $\lambda_{i}^{J}$ is the share of workers in sector $\mathrm{J}$ in constituency I, who voted for free trade and $1-\lambda_{i}^{J}$ is the share of workers of sector $\mathrm{J}$ who voted for protection. For example, assuming that $\mathrm{J}$ is the agricultural sector, $\lambda_{i}^{J}$ is the share of farmers who voted for free trade and $1-\lambda_{i}^{J}$ the share of farmers who voted for protection. Similarly, $\lambda_{i}^{-J}$ is the share of non-agricultural workers who voted for free trade, and $1-\lambda_{i}^{-J}$ is the share of non-agricultural workers who voted for protection. $\beta_{i}^{J}$ is the turnout of the workers in sector $\mathrm{J}$ in the constituency i. Clearly these parameters are the really relevant ones. If we can estimate these values, we obtain far more and better information about the voting behaviour of different sectors or, in our case, groups of farmers with different specialisations, than with the help of other approaches. 


\subsection{Goodman's approach}

One of the most prominent approaches to solving the problem of Ecological Inference relies on ecological regressions, which were developed by Leo Goodman (1953) and are therefore also called 'Goodman's Regression'. The design is simple. Referring to table 3, we know that:

$$
V_{i}=\lambda_{i}^{J}+\left(\lambda_{i}^{-J}-\lambda_{\mathrm{i}}^{\mathrm{J}}\right) *\left(1-\mathrm{X}_{\mathrm{i}}^{\mathrm{J}}\right)
$$

This equation has the same form as a simple two variable ordinary least squares (OLS) regression equation such as

$$
\mathrm{Y}=\mathrm{a}+\mathrm{bX}+\mathrm{e}
$$

where $\mathrm{Y}$ is the dependent variable, which is similar to $V_{i}$, the constant a equals $\lambda_{i}^{J},\left(1-\mathrm{X}_{\mathrm{i}}^{\mathrm{J}}\right)$ is the independent variable, $\left(\lambda_{i}^{-J}-\lambda_{\mathrm{i}}^{J}\right)$ is the estimated coefficient for the independent variable and $\mathrm{e}$ is the error term. This method uses information from all constituencies together to produce estimates. The disadvantage is that it often produces impossible results, such as negative coefficients or coefficients above one, which implies that more than 100 percent of votes were cast by members of a certain group of voters. Nevertheless, we first apply this simple regression in order check the robustness of the results we obtain with the help of the more sophisticated method, King's Algorithm.

Table 4 provides the estimates for the constant, i.e. $\lambda_{i}^{J}$. They show the same effects that already appear in figures 1 and 2 above: Smallholders seem to have voted for free trade (73.8 percent), whereas large land owners (row 4) seem to have preferred protection. The weaknesses of Goodman's regression are apparent here. Some of the estimated coefficients show negative signs, which implies that a negative number of voters from this particular group voted for free trade. Although this is logically of course impossible, the direction of voting behaviour provides useful information. Table 4 also shows the estimated coefficients for the autumn election. The effects still appear, although much weaker. Smallholders seem to have lost much of their preference for free trade. 
Table 4: Goodman coefficients = the estimated constant a (simple OLS with robust standard errors)

\begin{tabular}{|c|c|c|c|c|c|c|}
\hline & \multicolumn{3}{|c|}{ Spring Election } & \multicolumn{3}{|c|}{ Autumn election } \\
\hline & Goodman & Obs. & R-squared & Goodman & Obs. & R-squared \\
\hline $\begin{array}{l}\text { Agriculture } \\
\text { (1000-2000 Kronor) }\end{array}$ & $\begin{array}{l}0.738 \\
(2.62)^{\star *}\end{array}$ & 177 & 0.01 & $\begin{array}{l}0.099 \\
(0.44)\end{array}$ & 177 & 0.02 \\
\hline $\begin{array}{l}\text { Agriculture } \\
2000-10.000 \text { Kronor) }\end{array}$ & $\begin{array}{l}0.275 \\
(4.03)^{\star *}\end{array}$ & 172 & 0.10 & $\begin{array}{l}0.126 \\
(1.75)\end{array}$ & 172 & 0.16 \\
\hline $\begin{array}{l}\text { Agriculture } \\
\text { (10.000-30.000 Kronor) }\end{array}$ & $\begin{array}{l}-0.893 \\
(3.57)^{\star *}\end{array}$ & 176 & 0.23 & $\begin{array}{l}-0.857 \\
(2.88)^{\star \star}\end{array}$ & 176 & 0.17 \\
\hline $\begin{array}{l}\text { Agriculture } \\
\text { more than } 30.000 \text { Kronor) }\end{array}$ & $\begin{array}{l}-9.926 \\
(4.36)^{* *}\end{array}$ & 177 & 0.14 & $\begin{array}{l}-6.593 \\
(2.59)^{*}\end{array}$ & 177 & 0.06 \\
\hline $\begin{array}{l}\text { Owners of nonagricultural } \\
\text { Estates }\end{array}$ & $\begin{array}{l}1.081 \\
(12.69)^{\star *}\end{array}$ & 185 & 0.13 & $\begin{array}{l}1.132 \\
(11.76)^{\star *}\end{array}$ & 185 & 0.17 \\
\hline Leaseholders & $\begin{array}{l}-1.654 \\
(4.46)^{* *}\end{array}$ & 178 & 0.18 & $\begin{array}{l}-1.167 \\
(2.49)^{\star}\end{array}$ & 178 & 0.09 \\
\hline
\end{tabular}

Robust $t$ statistics in parentheses

Each observation was weighted with the number of voters per constituency.

*significant at $5 \%$; ** significant at $1 \%$

Note: The presented values are the estimates constant a in equation 2.

Table 5 provides the estimates for Goodman's regression, but now includes for some regressions a dummy for constituencies in which the numbers of voters from the particular group exceeded 30 percent of the total electorate. The dummy for the category of farmers owning the smallest amount of land is positive (0.325) and significant: Constituencies in which the number of voters who were smallholders exceeded 30 percent voted significantly more strongly for free trade. 
Table 5: Goodman coefficients = the estimated constant a (simple OLS with robust standard errors), including dummy for concentrated areas

\begin{tabular}{|c|c|c|c|c|c|c|}
\hline & \multicolumn{3}{|c|}{ Spring Election } & \multicolumn{3}{|c|}{ Autumn election } \\
\hline & Goodman & Obs. & R-Squared & Goodman & Obs. & R-Squared \\
\hline $\begin{array}{l}\text { Agriculture } \\
(1000-2000 \text { Kronen })>30 \%\end{array}$ & $\begin{array}{l}0.325 \\
(2.22)^{*}\end{array}$ & 177 & 0.03 & $\begin{array}{l}0.157 \\
(1.01) \\
\end{array}$ & 177 & 0.02 \\
\hline $\begin{array}{l}\text { Agriculture } \\
(1000-2000 \text { Kronen) }\end{array}$ & $\begin{array}{l}0.508 \\
(1.63) \\
\end{array}$ & & & $\begin{array}{l}-0.012 \\
(0.04) \\
\end{array}$ & & \\
\hline $\begin{array}{l}\text { Agriculture } \\
(2000-10.000 \text { Kronen })>30 \%\end{array}$ & $\begin{array}{l}0.106 \\
(1.03)\end{array}$ & 172 & 0.85 & $\begin{array}{l}0.080 \\
(0.77) \\
\end{array}$ & 172 & 0.16 \\
\hline $\begin{array}{l}\text { Agriculture } \\
(2000-10.000 \text { Kronen) }\end{array}$ & $\begin{array}{l}0.088 \\
(0.44)\end{array}$ & & & $\begin{array}{l}-0.015 \\
(0.08) \\
\end{array}$ & & \\
\hline $\begin{array}{l}\text { Owners of nonagricultural } \\
\text { estates }>30 \%\end{array}$ & $\begin{array}{l}-0.209 \\
(1.27) \\
\end{array}$ & 185 & 0.15 & $\begin{array}{l}-0.287 \\
(1.66) \\
\end{array}$ & 185 & 0.19 \\
\hline $\begin{array}{l}\text { Owners of nonagricultural } \\
\text { estates }\end{array}$ & $\begin{array}{l}1.510 \\
(4.31)^{* *}\end{array}$ & & & \begin{tabular}{|l|}
1.720 \\
$(4.82)^{\star *}$
\end{tabular} & & \\
\hline
\end{tabular}

Robust $\mathrm{t}$ statistics in parentheses

${ }^{*}$ significant at $5 \% ;{ }^{* *}$ significant at $1 \%$

Note: same estimation as in Table 4, but including a dummy which is equal to 1 if the number of voters owning estates of this particular value exceeds $30 \%$

Goodmans' regression already provide useful information, although the coefficients itself are not logically explainable. We therefore now turn to the alternative method, i.e. to Kings Algorithm that was mentioned above.

\subsection{King's algorithm}

The most advanced and modern tool for election analysis, and the only one that allows us to solve the Ecological Inference problem, is King's Algorithm. King (1997) starts out from the equation introduced by Goodman ${ }^{4}$ (1953), but combines it with the 'method of bounds'. The 'method of bounds' derives from the observation that we can deterministically put some limits on individual behaviour from the available aggregate data. Assume for instance that we observe two types of voters (wheat and dairy farmers) and two voting options (voting or not voting). The turnout in constituency i $\left(T_{i}\right)$ is just the proportion of wheat farmers who voted in this district $\left(\beta_{i}^{J}\right)$ times the share of wheat farmers in constituency i $\left(X_{i}\right)$, plus the proportion of dairy farmers who voted multiplied by the share of dairy farmers in this constituency:

$$
T_{i}=\beta_{i}^{J} X_{i}+\beta_{i}^{-J}\left(1-X_{i}\right)
$$

\footnotetext{
4 The simple Goodman regression however, does not estimate the turnout per group, but the votes for free
} trade in one step. 
Since we know the turnout, the true proportions of voters among wheat and dairy farmers must fall somewhere on a downward sloping line, whose slope is determined by the ratio of wheat farmers to dairy farmers, and whose intercepts will depend on the turnout as well:

$$
\begin{aligned}
& \beta_{i}^{J}=\frac{T_{i}}{X_{i}}-\beta_{i}^{-J} \frac{1-X_{i}}{X_{i}} \\
& \beta_{i}^{-J}=\frac{T_{i}}{1-X_{i}}-\beta_{i}^{J} \frac{X_{i}}{1-X_{i}}
\end{aligned}
$$

If we had only one set of aggregate data, for example information on the turnout and the share of farmers for the whole of Sweden, this would be as far as we could go, but we have aggregate data for every constituency. Each set of aggregate data, that is, each constituency, gives us such a line. They can all be drawn in one so-called tomography plot. This is informative, but does not provide enough information to get a clear solution. There is no exact way of recovering the values in the inner cells of table 3 . The simplest assumption to start with is that the true proportions for each constituency are picked at random from some distribution, but that all constituencies are drawn from the same population. King focuses on the case where that distribution fits the joint probabilities to a truncated bivariate normal distribution so that all proportions are between 0 and 1 . In order to get the parameters from the truncated bivariate normal distribution, King uses the lines from the above mentioned plot. The normality assumption helps detect the mode on the tomography plot, where most of the lines cross, and improves estimates by 'borrowing strength' from other constituencies. Intuitively, the most likely values for $\beta_{i}^{J}$ and $\beta_{i}^{-J}$ are nearest the mode. Adding a couple of modest assumptions, five intermediate parameters that define the truncated bivariate distribution are estimated via a maximum likelihood function. The parameters are then transformed and rescaled. The means of the distribution of $\beta_{i}^{J}$ and $\beta_{i}^{-J}$ are used as point estimates, and standard errors are based upon the variation in the simulated values. Thus King's Algorithm provides sub-estimates for every constituency and thereby extracts much more information from the available data than simpler econometric tools.

As a description of the methods used to estimate these parameters is beyond the scope of this paper, the interested reader is referred to King (1997) for more details. ${ }^{5}$ Owing to the lack of primary data on the agricultural specialisation of the voters, we do not use the shares of wheat and dairy farmers, but those of voters from different income groups and owning estates of different values. Table 6 reports the results for beta (turnout) and lambda (votes for free trade). On the left, the results are shown for all constituencies; on the right, for those constituencies where the several groups of voters made up more than 30 percent of the electorate. This was nowhere the case for voters who owned farms of between 10,000 and 30,000 Kronor, for leaseholders and for voters who owed their right to vote to their income. As the geo-

We estimated the quantities of interest applying Benoit and King's (2003) Ezi software. 
graphical location of the voters here does not concern us, we can include at least part of these voters in the analysis. Our assumption is that those in the lowest income bracket (800 to 1000 Kronor) reported in the national statistics earned wages, whereas those in the highest bracket (more than 5000 Kronor) derived their income from capital. 


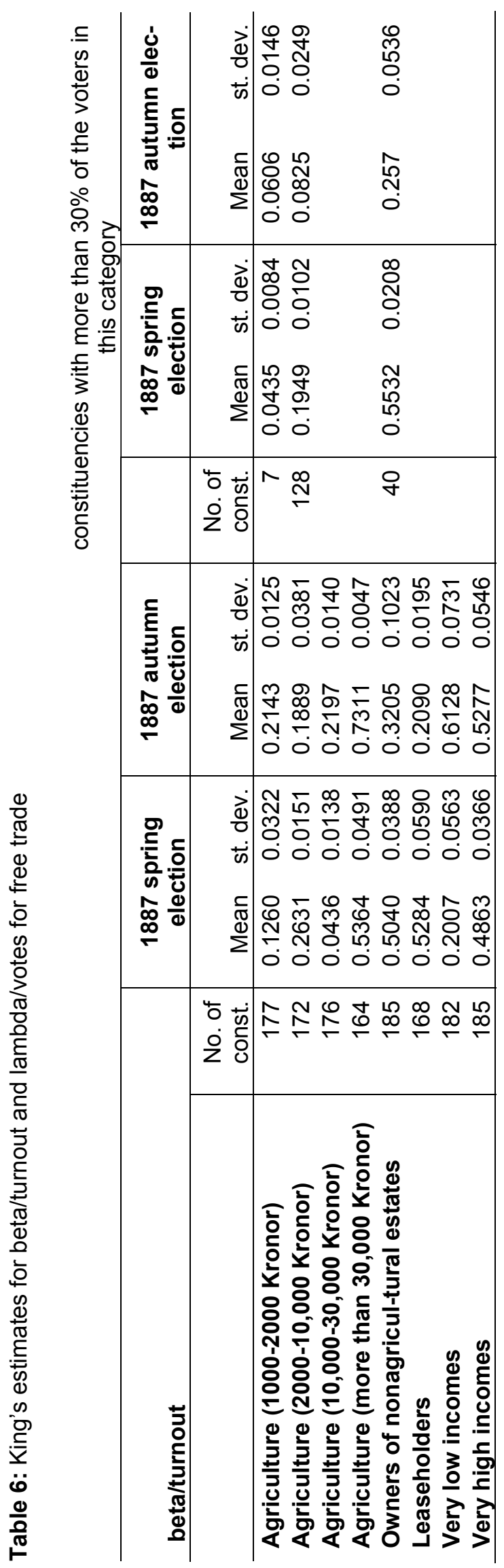

\begin{tabular}{|c|c|c|c|}
\hline 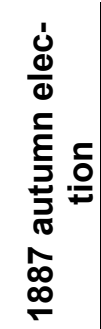 & 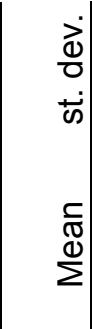 & 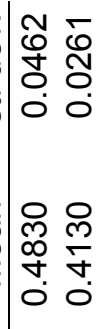 & 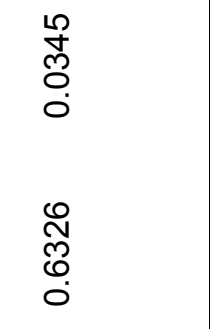 \\
\hline 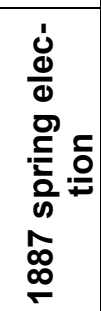 & $\begin{array}{l}\dot{\mathrm{d}} \\
\frac{0}{0} \\
\dot{\omega} \\
\dot{\Phi} \\
\stackrel{0}{2}\end{array}$ & 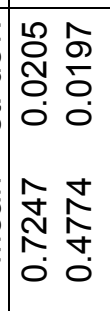 & $\begin{array}{l} \pm \\
0 \\
0 \\
0 \\
0 \\
0 \\
o \\
0 \\
\stackrel{0}{0}\end{array}$ \\
\hline & 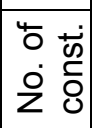 & $\stackrel{\sim}{\sim}$ & q \\
\hline 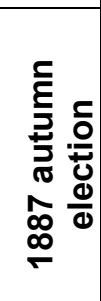 & 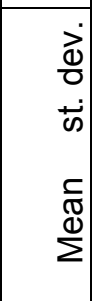 & 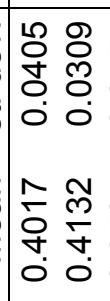 & 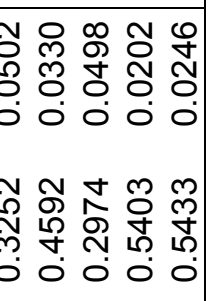 \\
\hline 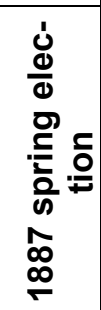 & $\begin{array}{l}\dot{\vec{d}} \\
\dot{0} \\
\dot{\omega} \\
\frac{\square}{\pi} \\
\dot{\Phi}\end{array}$ & 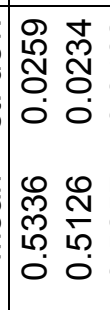 & 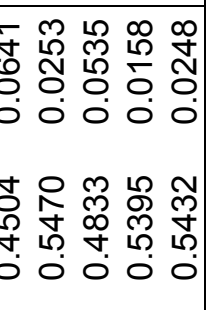 \\
\hline \multirow[b]{2}{*}{$\begin{array}{l}0 \\
0 \\
0 \\
\Phi \\
0\end{array}$} & 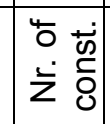 & \multicolumn{2}{|c|}{ 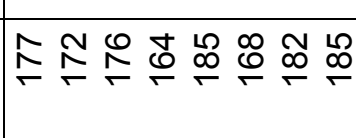 } \\
\hline & & 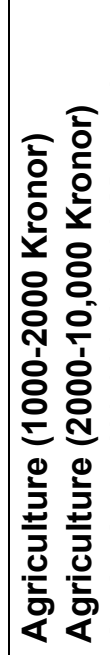 & 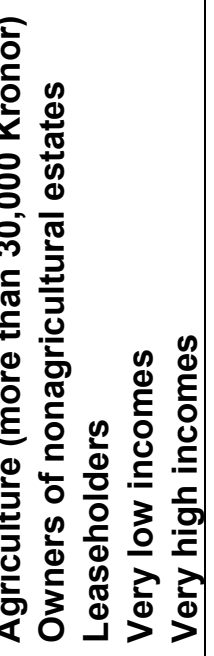 \\
\hline
\end{tabular}


The results shown in table 6 evidence that generally, turnout was quiet low, particularly so for farmers with very little land and farmers with estates whose value exceeded the average $(10,000$ to 30,000 Kronor). However, among smallholders turnout increased between spring and autumn 1887. It also increased among richer estate owners (more than 10,000 Kronor), but fell of among middling farmers (2000 to 10,000 Kronor). This decline is even more obvious when we separately consider the 128 constituencies where such middling farmers made up more than 30 percent of the electorate.

As for lambda, i.e. free trade support, both groups of voters who had the right to vote because they earned a yearly income of above 800 kronor had a slight preference for free trade. This did not appreciably change between spring and autumn 1887. Obviously, low income wage earners were opposed to agricultural protection because this would have increased the price of food. The behaviour of high income capitalists fits expectations derived from Bohlin's (2009: $33 \mathrm{f}$.) analysis of the impact of tariffs: agricultural tariffs harmed the members of this group, too. In contrast to them, agriculture did not vote homogeneously. In spring 1887, smallholders preferred free trade - even more so in regions where they were very concentrated, constituting more than 30 percent of the voters. Large landowners, by contrast, preferred protection. However, in the autumn election the picture changed. Even smallholders now developed a preference for protectionism. Only where small farmers were concentrated did free trade supporters remain dominant. The changes may either indicate electoral manipulation in constituencies where large landowners were able to put pressure on smallholders, or the possibility that small farmers became convinced that protectionism would be the optimal policy for them as well. Below we will return to this question.

First, however, we need to determine if the association between farm size (respectively value) and agricultural specialisation can be detected in voting behaviour, too. We do this by selecting the 30 percent of the constituencies where the output of wheat and the density of cows per hectare farmland were highest, and by estimating the share of votes for free trade for these districts only. Table 7 shows the results for the constituencies dominated by wheat and by dairy farming. 
Table 7: King's estimates for lambda/votes for free trade (30 percent wheat and 30 percent dairy farming dominated constituencies only)

\begin{tabular}{|c|c|c|c|c|c|}
\hline & & $\begin{array}{r}1887 \text { elec } \\
\text { elec }\end{array}$ & $\begin{array}{l}\text { pring } \\
\text { ion }\end{array}$ & $\begin{array}{r}1887 \text { a } \\
\text { elec }\end{array}$ & $\begin{array}{l}\text { utumn } \\
\text { tion }\end{array}$ \\
\hline Wheat farming dominated constituencies & $\begin{array}{l}\text { No. of } \\
\text { const. }\end{array}$ & Mean & $\begin{array}{l}\text { st. } \\
\text { dev. }\end{array}$ & Mean & $\begin{array}{l}\text { st. } \\
\text { dev. }\end{array}$ \\
\hline Agriculture (1000-2000 Kronor) & 48 & 0.434 & 0.025 & 0.318 & 0.036 \\
\hline Agriculture (2000-10,000 Kronor) & 45 & 0.396 & 0.026 & 0.316 & 0.030 \\
\hline Agriculture $(10,000-30,000$ Kronor $)$ & 49 & 0.444 & 0.048 & 0.300 & 0.041 \\
\hline Agriculture (more than 30,000 Kronor) & 49 & 0.379 & 0.061 & 0.270 & 0.042 \\
\hline Owners of nonagricultural estates & 54 & 0.472 & 0.024 & 0.394 & 0.028 \\
\hline Leaseholders & 47 & 0.394 & 0.052 & 0.231 & 0.045 \\
\hline Very low incomes & 54 & 0.461 & 0.016 & 0.463 & 0.021 \\
\hline Very high incomes & 54 & 0.467 & 0.024 & 0.467 & 0.024 \\
\hline Dairy farming dominated constitue & & & & & \\
\hline Agriculture (1000-2000 Kronor) & 48 & 0.640 & 0.027 & 0.439 & 0.04 \\
\hline Agriculture (2000-10,000 Kronor) & 48 & 0.620 & 0.026 & 0.464 & 0.04 \\
\hline Agriculture $(10,000-30,000$ Kronor $)$ & 48 & 0.609 & 0.050 & 0.404 & 0.05 \\
\hline Agriculture (more than 30,000 Kronor) & 43 & 0.512 & 0.070 & 0.335 & 0.06 \\
\hline Owners of nonagricultural estates & 52 & 0.669 & 0.024 & 0.548 & 0.03 \\
\hline Leaseholders & 46 & 0.551 & 0.063 & 0.303 & 0.06 \\
\hline Very low incomes & 51 & 0.669 & 0.016 & 0.669 & 0.02 \\
\hline Very high incomes & 52 & 0.665 & 0.025 & 0.664 & 0.03 \\
\hline
\end{tabular}

The analysis bears out our core hypothesis that wheat producers favoured protection much more strongly than dairy farmers. This was the case in both elections. In dairy districts, owners of very large estates and leaseholders were the only groups whose support for free trade fell under 60 percent in the election in spring 1887 . The contrast to the constituencies where wheat farming dominated could not be stronger. There, in spring 1887 support for free trade nowhere reached 50 percent; even c. 57 percent of the smallholders whose farms had a value of 1000 to $2000 \mathrm{Kro}-$ nor voted for protection. By autumn, the picture had changed markedly. The general tendency of voters from dairy districts to be more supportive of free trade than voters from wheat districts remained, but free trade support diminished in both types of constituencies and among almost all groups of voters. The only group where it slightly increased were voters who had gained their right to participate in elections because they had a taxable income of at least 800 kronor per year, and who fell in the poorest category within this group. Conceivably, in the face of intensifying protectionist propaganda these voters became increasingly worried about food prices.

There is one final question we need to examine: that of the causes of the break down of the free trade vote between spring and autumn 1887. Was this due to manipulation or rather to a change of mind among erstwhile opponents of protectionism? As for possible manipulations, our hypothesis is that these would most likely occur in constituencies where the elections were indirect, as here occasionally open voting was still practiced. Accordingly, we select the indirect constituencies and analyse them separately, expecting the smallholders' vote for free trade to have been weaker here than the in the mean of all Swedish constituencies (cf. table 6). Table 8 shows the results. 
Table 8: King's estimates for lambda/votes for free trade (constituencies where voting was indirect)

\begin{tabular}{|c|c|c|c|c|c|c|}
\hline \multirow[b]{2}{*}{ Indirect constituencies } & \multicolumn{3}{|c|}{1887 spring election } & \multicolumn{3}{|c|}{1887 autumn election } \\
\hline & $\begin{array}{l}\text { No. of } \\
\text { const. }\end{array}$ & Mean & $\begin{array}{l}\text { st. } \\
\text { dev. }\end{array}$ & $\begin{array}{l}\text { No. of } \\
\text { const. }\end{array}$ & Mean & $\begin{array}{l}\text { st. } \\
\text { dev. }\end{array}$ \\
\hline Agriculture (1000-2000 Kronor) & 59 & 0.566 & 0.018 & 40 & 0.414 & 0.031 \\
\hline Agriculture (2000-10,000 Kronor) & 58 & 0.550 & 0.016 & 40 & 0.426 & 0.022 \\
\hline Agriculture $(10,000-30,000$ Kronor $)$ & 58 & 0.560 & 0.033 & 41 & 0.397 & 0.038 \\
\hline Agriculture (more than 30,000 Kronor) & 50 & 0.461 & 0.049 & 36 & 0.336 & 0.033 \\
\hline Owners of nonagricultural estates & 60 & 0.574 & 0.019 & 41 & 0.441 & 0.026 \\
\hline Leaseholders & 55 & 0.516 & 0.036 & 39 & 0.325 & 0.040 \\
\hline Very low incomes & 59 & 0.574 & 0.012 & 40 & 0.510 & 0.015 \\
\hline Very high incomes & 60 & 0.572 & 0.018 & 41 & 0.506 & 0.017 \\
\hline
\end{tabular}

Our estimates based on King's algorithm show that in actual fact the opposite was true. In indirect constituencies, the vote for free trade was in both elections stronger than on average, i.e. when all Sweden is considered. If there was any electoral manipulation at all, it was clearly not associated with districts where voting was indirect and possibly not secret. This leaves us with one conclusion: In the course of the summer 1887, some farmers who in spring had still voted for free trade changed their political allegiance and became supporters of protectionism.

\section{Conclusion}

In 1888, the Swedish government introduced tariffs for a number of agricultural and industrial goods. Frequently regarded as the outcome of a 'quirk of fate', to use Lewin's (1988: 47) expression - i.e. of a tax scandal that cost the free trade supporting members for Stockholm their seats in parliament -, this change in policies would actually have been impossible without the severe losses that the free traders suffered in the general election of autumn 1887. If these losses had not occurred, the protectionists would have had to discover at least three other parliamentarians who favoured free trade and had failed to pay their taxes (i.e. 26 instead of 23) in order to gain a majority in parliament. Thus, while the first general election of 1887 kept the free traders in power for another six months, the second election did really play a crucial role in the realignment of Sweden's tariff policies a year later.

In the present article, we ask how and why this shift in voting behaviour came about. Specifically, we ask which groups of voters voted for free trade in the two elections, and examine if their decisions match expectations that can be formed on the basis of trade models such as the specific factor models, that is, if voting behaviour can be considered rational.

In order to answer these questions, we first determine which groups of voters would have benefited from protectionism and which would have suffered. We do this on the basis of information on their income and on the amounts of land they owned or leased, and of data on farm sizes and the mix of agricultural outputs produced in the constituencies. This data allows us to determine that there was a close association between the size of the voters' estates and their agricultural specialisation, with voters who owned or leased large estates producing import competing com- 
modities such as wheat. Smallholders, by contrast, focused on animal husbandry and were threatened by international competition to a much smaller degree or not at all.

In our analysis, we first apply Goodman's approach to election analysis in order to provides robustness checks for the results we obtain with the more modern and sophisticated method, i.e. King's algorithm. We find that voters who did not own or lease land consistently favoured free trade. Agricultural voters, however, evidenced interesting variations between estate sizes, and important changes between the spring and autumn elections. In the spring election, it were only the voters with the largest farms (that had a value of more than 30,000 Kronor) and leaseholders (who had to rent land with a value of at least 6000 Kronor in order to be allowed to vote) whose support for free trade fell below 50 percent. In the autumn election, by contrast, even 60 percent of the smallholders voted for protection. By separately analysing constituencies where voting was indirect and occasionally still open, we determine that electoral manipulation or pressure that the owners of large estates exerted on smallholders is unlikely to be responsible for this shift. Apparently, small and middling farmers decisively changed their trade political outlook between spring and autumn 1887. As trade balances did not change so quickly, some other influence - likely enough protectionist propaganda - must have had a crucial impact in the course of the summer months 1887 . Apparently, not only farmers who were really exposed to competition from abroad, such as wheat producers, were susceptible to anti-free trade arguments, but small farmers who specialised in dairy production, too. For the protectionists, disinformation seems to have paid. 


\section{Appendix: Maps}

Figure 3: Wheat farming 1885

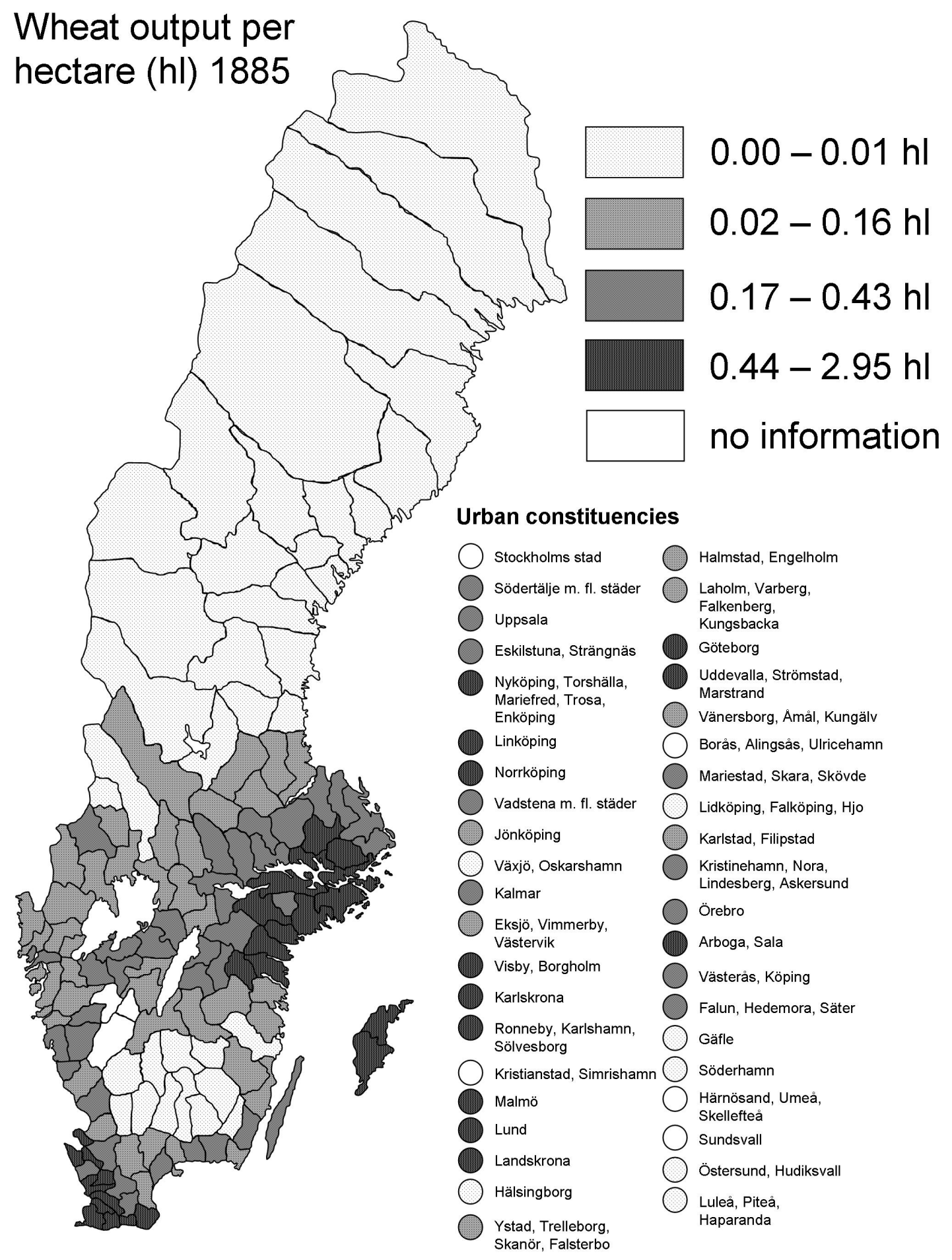

Source: BISOS (1890). 
Figure 4: Rye farming 1885

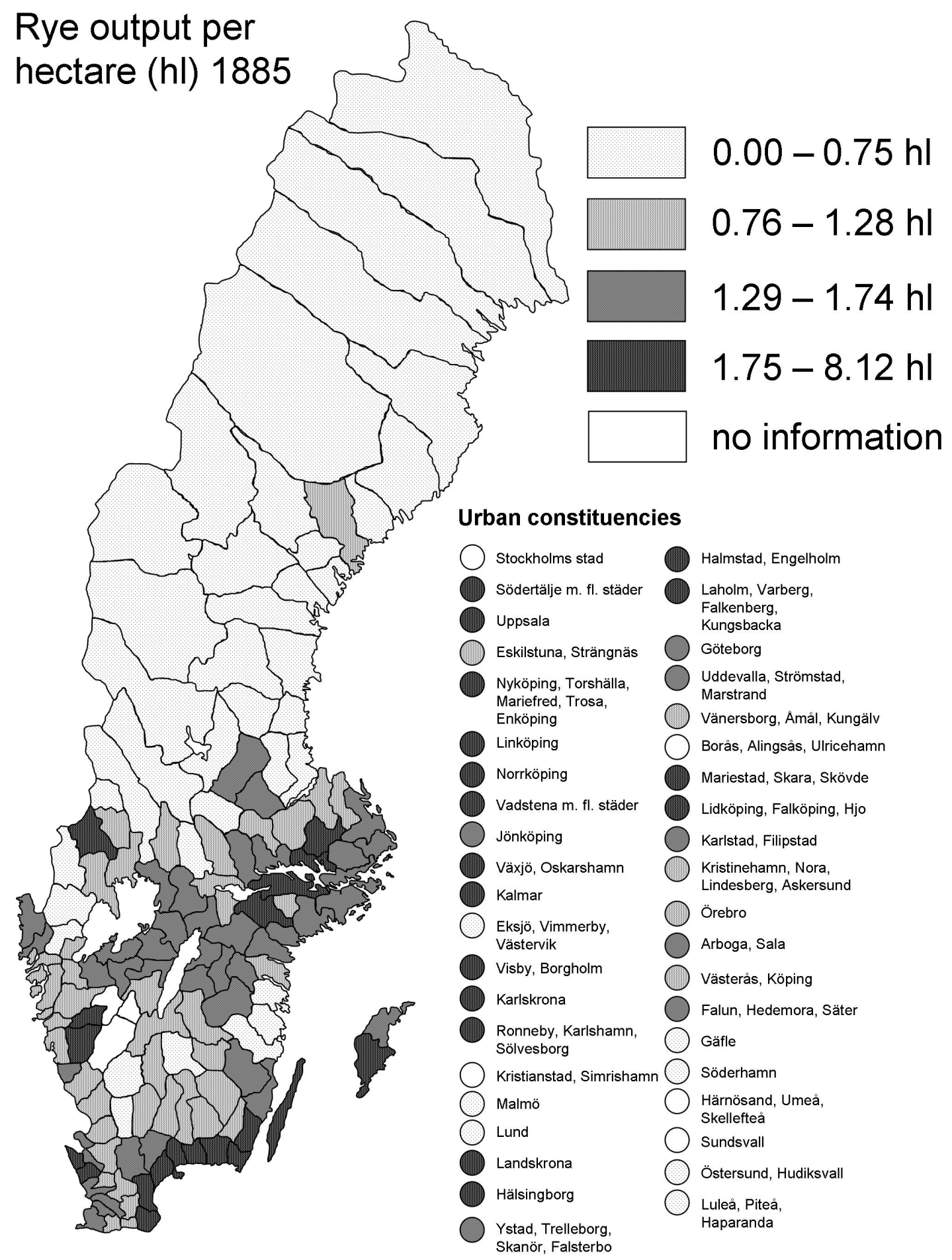

Source: BISOS (1890). 
Figure 5: Dairy farming 1885

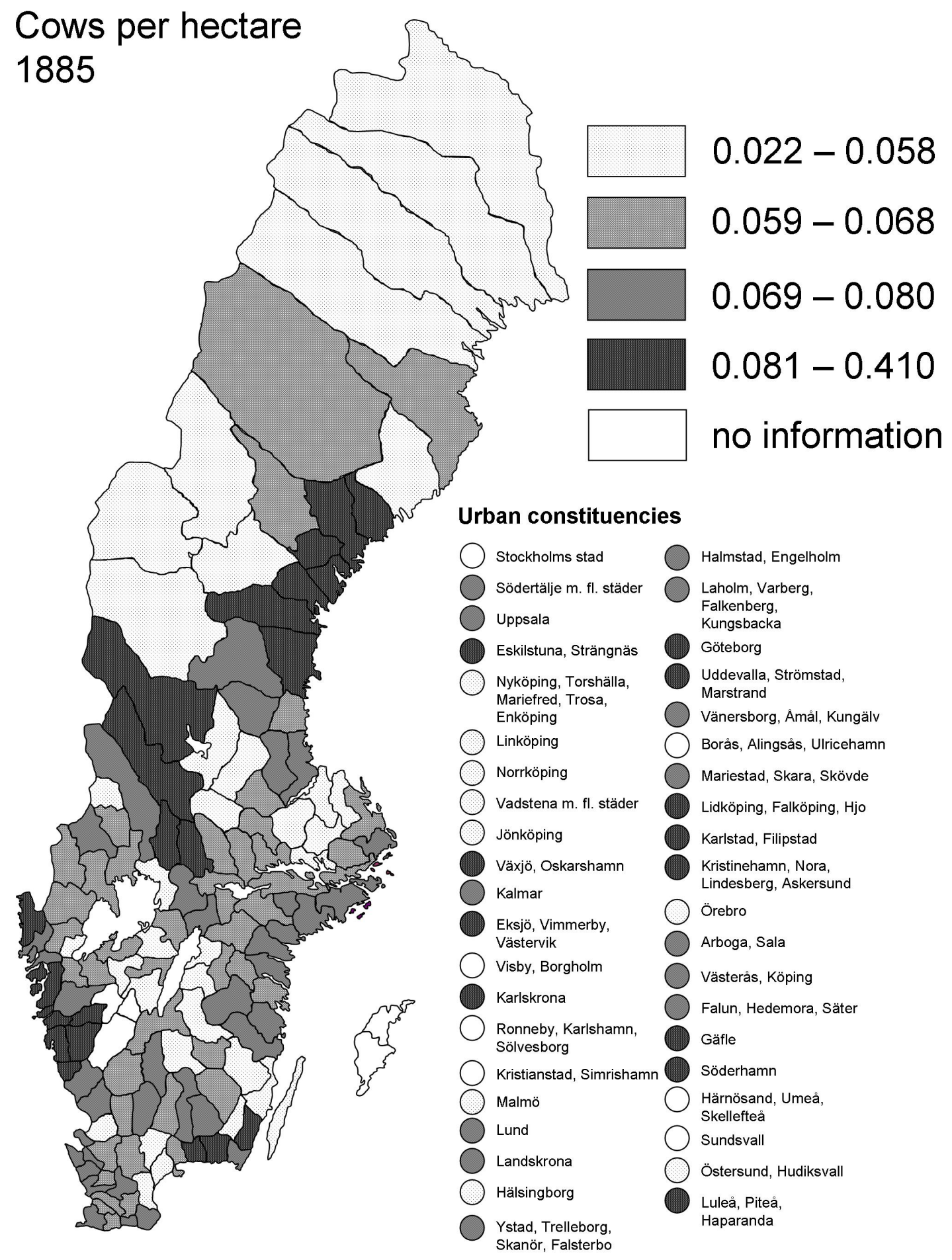

Source: BISOS (1890). 
Figure 6: Pig farming 1885

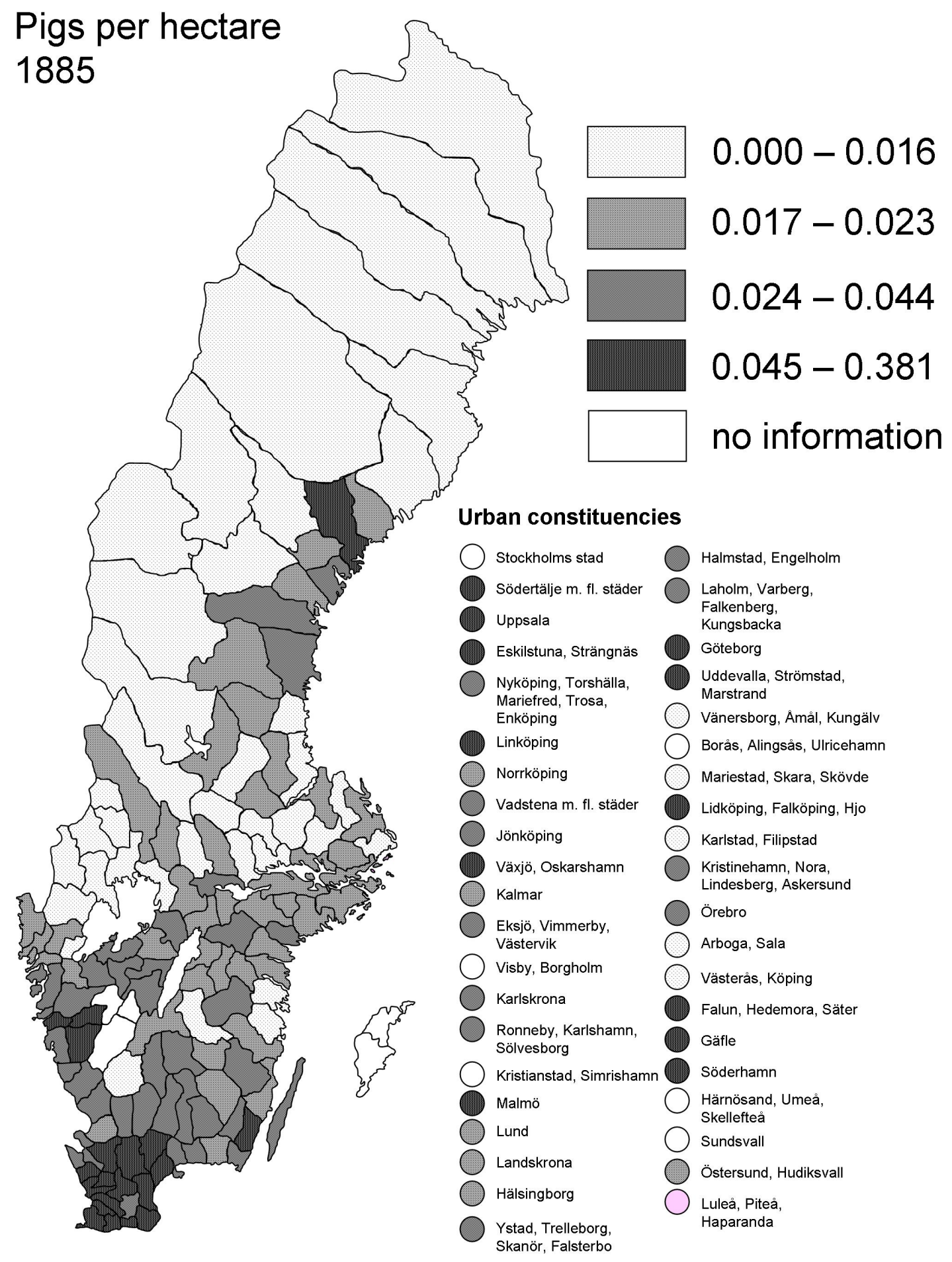

Source: BISOS (1890). 


\section{References}

Anderson, I. (1955/70). A History of Sweden. London: Weidenfeld and Nicolson.

Benoit, K. and King, G. (2003). A Program for Ecological Inference. In. Kent, Washington: Published as part of the Gauss Package by Aptech Systems and as a stand-alone program called EzI: A(n Easy) Program for Ecological Inference.

BISOS (1885). Bidrag till Sveriges officiela Statistik, vol. R) Valstatistik, VII.3. Stockholm: Kungl. Boktryckeriet.

BISOS (1887). Bidrag till Sveriges officiela statistik, vol. R) Valstatistik, VII:1 Stockholm: Kungl. Boktryckeriet.

BISOS (1888). Bidrag till Sveriges officiela statistik, vol. R) Valstatistik. VIII. Stockholm: Kungl. Boktryckeriet.

BISOS (1890). Bidrag till Sveriges officiela statistik, vol. N) Jordbruk och boskapsskötsel, XXIV. Stockholm: P. A. Norstedt \& söner.

Bohlin, J. (2005). Tariff Protection in Sweden 1885-1914. Scandinavian Economic History Review LIII, 7-26.

Bohlin, J. (2009). The Income Distributional Consequences of Agrarian Tariffs in Sweden on the Eve of World War I. European Review of Economic History 13, 1-45.

Caramani, D. (2000). Elections in Western Europe since 1815. In The Societies of Europe. New York: Grove.

Esaiasson, P. (1990). Svenska Valkampanjer 1866 - 1988. Stockholm: Allmänna Förlaget.

Gerschenkron, A. (1943). Bread and Democracy in Germany. Berkeley: University of California Press.

Goodman, L. A. (1953). Ecological Regressions and Behavior of Individuals. American Sociological Review 18, 663-664.

Håstad, E. (1941). Tullstridens val och folkmenigen. In Festskrift till professor skytteanus Axel Brusewitz. Uppsala: Almqvist and Wicksell, 105-153.

Höijer, E. (1921). Tabeller till belysning av det Svenska jordbrukets utveckling 1871-1919. Stockholm: Isaac Marcus' Boktryckeri-Aktiebolag.

Jörberg, L. (1972). A History of Prices in Sweden 1732-1914, vol. 1: Sources, Methods, Tables. Lund: CWK Gleerup. 
King, G. (1997). A Solution to the Ecological Inference Problem. Princeton: Princeton University Press.

King, G., Rosen, O., Tanner, M. and Wagner, A. F. (2008). Ordinary Economic Voting Behavior in the Extraordinary Election of Adolf Hitler. Journal of Economic History 68, 951-996.

Klug, A. (2001). Why Chamberlain Failed and Bismarck Succeeded: The Political Economy of Trade Tariffs in British and German Elections. European Review of Economic History, 219-250.

Lehmann, S. H. (2010). The German Elections in the 1870s: Why Germany Turned From Liberalism to Protectionism. Journal of Economic History 70, 1-32.

Lewin, L. (1988). Ideology and Strategy: A Century of Swedish Policies. Cambridge: Cambridge University Press.

Lewin, L., Jansson, B. and Soerbom, D. (1976). The Swedish Electorate 1887-1968. Stockholm: Almqvist and Wicksell.

Lindahl, E., Dahlgren, E. and Kock, K. (1937). Wages, Cost of Living and National Income in Sweden 1860-1930, vol. 3: National Income of Sweden 1861-1930, Part two. London: P.S. King \& Son.

National Central Bureau of Statistics (1972). Historical Statistics of Sweden, vol. 3: Foreign trade 1732-1970. Stockholm: Allmanna Forlaget.

O'Rourke, K. (1997). The European Grain Invasion. The Journal of Economic History 57, 775801.

Ogburn, W. F. and Goltra, I. (1919). How Women Vote: A Study on an Election in Portland, Oregon. Political Science Quarterly 34, 414-433.

Särlvik, B. (2002). Party and Electoral Systems in Sweden. In The Evolution of Electoral and Party Systems in the Nordic Countries (eds. Grofman, B. and Lijphart, A.). New York: Agathon Press, 225-269.

Schonhardt-Bailey, C. (1998). Parties and Interests in the "Marriage of Iron and Rye". British Journal of Political Science 28, 291-330.

Verney, D. V. (1957). Parliamentary Reform in Sweden 1866-1921. Oxford: Clarendon Press.

Viner, J. (1931). Cost Curves and Supply Curves. Zeitschrift fur Nationalokonomie 3, 23-46.

Webb, S. B. (1982). Agricultural Protection in Wilhelmine Germany: Forging an Empire with Pork and Rye. Journal of Economic History 42, 309-326. 